\title{
A Whole-Cell Biosensor for the Detection of Gold
}

\author{
Carla M. Zammit ${ }^{1,2 *}$, Davide Quaranta ${ }^{3}$, Shane Gibson ${ }^{3}$, Anita J. Zaitouna ${ }^{4}$, Christine Ta ${ }^{5}$, Joël Brugger ${ }^{1,6}$, \\ Rebecca Y. Lai ${ }^{4}$, Gregor Grass ${ }^{3,7}$, Frank Reith ${ }^{1,2 *}$
}

1 The University of Adelaide, School of Earth and Environmental Sciences, Centre of Tectonics, Resources and Exploration (TRaX), Adelaide, South Australia, Australia, 2 The Commonwealth Scientific and Industrial Research Organisation (CSIRO) Land and Water, Environmental Biogeochemistry, PMB2, Glen Osmond, South Australia, Australia, 3 The University of Nebraska-Lincoln, School of Biological Sciences, Lincoln, Nebraska, United States of America, 4 The University of Nebraska-Lincoln, Department of Chemistry, Lincoln, Nebraska, United States of America, 5 Flinders University, School of Chemical and Physical Sciences, Adelaide, South Australia, Australia, 6 Mineralogy, South Australian Museum, Adelaide, South Australia, Australia, 7 Bundeswehr Institute of Microbiology, Munich, Germany

\begin{abstract}
Geochemical exploration for gold $(\mathrm{Au})$ is becoming increasingly important to the mining industry. Current processes for Au analyses require sampling materials to be taken from often remote localities. Samples are then transported to a laboratory equipped with suitable analytical facilities, such as Inductively Coupled Plasma-Mass Spectrometry (ICP-MS) or Instrumental Neutron Activation Analysis (INAA). Determining the concentration of Au in samples may take several weeks, leading to long delays in exploration campaigns. Hence, a method for the on-site analysis of $\mathrm{Au}$, such as a biosensor, will greatly benefit the exploration industry. The golTSB genes from Salmonella enterica serovar typhimurium are selectively induced by $\mathrm{Au}(\mathrm{I} / \mathrm{III})$-complexes. In the present study, the golTSB operon with a reporter gene, lacZ, was introduced into Escherichia coli. The induction of golTSB::IacZ with $\mathrm{Au}(\mathrm{I} / \mathrm{III})$-complexes was tested using a colorimetric $\beta$-galactosidase and an electrochemical assay. Measurements of the $\beta$-galactosidase activity for concentrations of both $\mathrm{Au}(\mathrm{I})$ - and $\mathrm{Au}(\mathrm{III})$-complexes ranging from 0.1 to $5 \mu \mathrm{M}$ (equivalent to 20 to $1000 \mathrm{ng} \mathrm{g}^{-1}$ or parts-per-billion (ppb)) were accurately quantified. When testing the ability of the biosensor to detect $\mathrm{Au}(\mathrm{I} / \mathrm{III})$-complexes $(\mathrm{aq})$ in the presence of other metal ions $(\mathrm{Ag}(\mathrm{I}), \mathrm{Cu}(\mathrm{II}), \mathrm{Fe}(\mathrm{III})$, $\mathrm{Ni}(\mathrm{II}), \mathrm{Co}(\mathrm{II}), \mathrm{Zn}, \mathrm{As}(\mathrm{III}), \mathrm{Pb}(\mathrm{II}), \mathrm{Sb}(\mathrm{III})$ or $\mathrm{Bi}(\mathrm{III}))$, cross-reactivity was observed, i.e. the amount of Au measured was either underor over-estimated. To assess if the biosensor would work with natural samples, soils with different physiochemical properties were spiked with Au-complexes. Subsequently, a selective extraction using $1 \mathrm{M}$ thiosulfate was applied to extract the $\mathrm{Au}$. The results showed that Au could be measured in these extracts with the same accuracy as ICP-MS $(P<0.05)$. This demonstrates that by combining selective extraction with the biosensor system the concentration of Au can be accurately measured, down to a quantification limit of $20 \mathrm{ppb}(0.1 \mu \mathrm{M})$ and a detection limit of $2 \mathrm{ppb}(0.01 \mu \mathrm{M})$.
\end{abstract}

Citation: Zammit CM, Quaranta D, Gibson S, Zaitouna AJ, Ta C, et al. (2013) A Whole-Cell Biosensor for the Detection of Gold. PLoS ONE 8(8): e69292. doi:10.1371/ journal.pone.0069292

Editor: Vipul Bansal, RMIT University, Australia

Received July 14, 2011; Accepted June 12, 2013; Published August 9, 2013

Copyright: (c) 2013 Zammit et al. This is an open-access article distributed under the terms of the Creative Commons Attribution License, which permits unrestricted use, distribution, and reproduction in any medium, provided the original author and source are credited.

Funding: This study was funded via an Australian Research Council (ARC) Linkage Grant and the following partners Commonwealth Scientific and Industrial Research Organisation, The University of Adelaide, Newmont Exploration Proprietary Limited and Barrick Gold of Australia Limited, the Institute for Mineral and Energy Resources and the Centre for Tectonics, Resources and Exploration. The funders had no role in study design, data collection and analysis, decision to publish, or preparation of the manuscript.

Competing Interests: The authors have read the journal's policy and have the following conflict: Newmont Exploration Proprietary Limited and Barrick Gold of Australia Limited helped fund this study. This does not alter the authors' adherence to all of the PLOS ONE policies on sharing data and materials.

* E-mail: carla.zammit@adelaide.edu.au (CMZ); Frank.Reith@csiro.au (FR)

\section{Introduction}

In recent years the market price of $\mathrm{Au}$ has steadily increased and currently stands at approximately USD $\$ 1,600$ per ounce (2013). This price rise has been driven by the growing demand for $\mathrm{Au}$ : for use in jewellery, particularly in middle-eastern and east Asian countries; for components in modern technologies; and, as a form of investment and security for governments and the financial sector [1]. The price and demand of Au may be rising, but the supply of $\mathrm{Au}$ is stagnating and exploration for new deposits is becoming less successful [2].

In spite of the progress achieved using geochemical and geophysical techniques, exploration for new $\mathrm{Au}$ deposits is technically challenging [3]. In recent years the discovery of world-class $\mathrm{Au}$ deposits has been sporadic and rare. The main reason is that outcropping deposits and those with obvious geophysical and geochemical signatures have already been discovered [4]. Hence, Au exploration in many countries is journeying into landscapes where thick layers of in situ or transported weathered materials (regolith) cover deeply buried mineralization $[2,5]$. In these areas, weathering of the underlying deposits and prolonged dispersion of metals has left geochemical haloes of $\mathrm{Au}$ and its pathfinder elements such as $\mathrm{Ag}, \mathrm{As}, \mathrm{Bi}, \mathrm{Mo}$, $\mathrm{Pb}$, Se and $\mathrm{W}[6]$ in overlying soils and weathered material (such as calcrete or ferricrete) [7,8]. Therefore, to successfully explore for $\mathrm{Au}$ in these uncharted terrains, new techniques are required to increase the success of exploration campaigns.

Geophysical methods are commonly used for the initial identification of areas with prospective Au mineralization [4]. Subsequent geochemical sampling targets particular types of surface materials, e.g., soils, calcrete or ferricrete [7,9]. These samples are transported to a laboratory, extracted using total selective extraction techniques and analyzed for $\mathrm{Au}$ and its 'pathfinder' elements [10,11]. Particular selective extraction techniques are now commonly used as they allow for the extraction of $\mathrm{Au}$ that is associated within operationally-defined 
phases, e.g. organics, iron oxides, clays or carbonates, and soil or regolith materials $[9,11,12,13,14]$. To achieve this, the use of solutions containing lixiviants, such as, thiosulfate, hydroxylaminehydrochloride or sodium pyrophosphate is common [9]. Techniques such as Inductively Coupled Plasma-Mass Spectrometry (ICP-MS) or Instrumental Neutron Activation Analysis (INAA) are then used to detect and quantify $\mathrm{Au}$ in extraction solutions or solid samples, respectively. The results from these analyses are reported back to exploration teams and decisions in regards to further investigation are evaluated. The entire process can take up to several weeks and requires complex analytical instrumentation used in dedicated laboratories. Hence, a reliable on-site test for $\mathrm{Au}$ will be of great benefit, as it will provide an on-the-spot assessment of $\mathrm{Au}$ in the area, allowing geologists to 'hone-in' on areas of interest.

The development of biosensing technologies for mineral exploration holds value in the speed, portability and potentially high selectivity and sensitivity of the assay $[15,16]$. Additionally, biosensing devices may aid in mineral processing, providing 'inline' analysis of ores and process waters, and assisting in the tailoring of the processing method to maximize Au extraction and minimize chemical consumption. To date, research into biosensors has focused around the detection and monitoring of heavy metal contamination, blood glucose levels, pathogens, food toxins, and illicit drugs [16]. Conversely, little research has been conducted on the use of biosensors for the minerals industry [17]. A biosensor consists of a biological element that is affected by an external stimulus: this effect is then manipulated into a measurable signal, which is used to elucidate qualitative or quantitative information about the initial stimuli [16]. For the development of a $\mathrm{Au}$ biosensor, biological elements that respond to Au are required.

To develop a commercially applicable Au biosensor for geochemical exploration campaigns a number of challenges have to be overcome. One of these challenges comes from the fact that the concentration and speciation of $\mathrm{Au}$ (i.e., oxidation state, complexing ligand and stability of aqueous complexes) determines its toxicity to cells $[18,19]$. In contrast to other heavy metals, Au does not form free ions in aqueous solution at surface conditions, but occurs in solution only as aurous (I) or auric (III) complexes [20]. Based on thermodynamic calculations and natural abundances of possible ligands, complexes with chloride, thiosulfate, ammonium and cyanide appear to be the most important $\mathrm{Au}$ complexes under surface conditions (e.g., [6]). Hence, the speciation of $\mathrm{Au}$, and not only its concentration, determines its toxicity, and consequently the genetic and biochemical responses of biosensors [19].

Another issue may lie in an unspecific microbial responses to toxic metals, highlighting one of the major challenges for the development of useful biosensors. Recent research has shown that the metallophillic bacterium Cupriavidus metallidurans, which forms biofilms on $\mathrm{Au}$ grains, rapidly accumulates Au-complexes from solution into the cell $[18,21,22,23]$. This is the result of $\mathrm{Au}(\mathrm{I} / \mathrm{III})-$ regulated gene expression, leading to energy-dependent reductive precipitation of toxic Au-complexes [18]. However, most of the defence mechanisms utilized by bacteria, such as C. metallidurans, are nonspecific responses to ranges of toxic metals, such as $\mathrm{Cu}(\mathrm{II})$ or $\operatorname{Ag}(\mathrm{I})$, rather than just $\mathrm{Au}(\mathrm{I} / \mathrm{III})[18,19,24]$.

In contrast, Salmonella enterica serovar typhimurium strain LT2 contains the golTSB regulon, which holds potential as the biological basis of a Au biosensor [25]. The golTSB operon works to detoxify the cell from harmful $\mathrm{Au}(\mathrm{I})$-and $\mathrm{Au}(\mathrm{III})$-complexes in the following way: GolS regulates the transcription of the other two genes in the operon; GolT is a transmembrane efflux ATPase; and GolB acts as a metallochaperone. Checa et al. (2007) [25] found that expression of $g_{0} l B$ increased in the presence of $\mathrm{Au}(\mathrm{III})$ complexes, but not in the presence of other metal ions such as $\mathrm{Cu}(\mathrm{II}), \mathrm{Ag}(\mathrm{I}), \mathrm{Zn}(\mathrm{II}), \mathrm{Cd}(\mathrm{II}), \mathrm{Hg}(\mathrm{II}), \mathrm{Fe}(\mathrm{II}), \mathrm{Co}(\mathrm{II}), \mathrm{Ni}(\mathrm{II}), \mathrm{Pb}(\mathrm{II})$, making the golTSB regulon an ideal chassis for the development of a $\mathrm{Au}$ biosensor for geochemical exploration. A biosensor system, developed by Checa et al. (2011), was capable of detecting but not quantifying $\mathrm{Au}$ : quantification is crucially important for geochemical exploration [26]. In addition, implementation of a biosensor on field samples is often met with little success due to the complex composition of environmental samples. Thus, an extraction method needs to be applied that solubilizes Au from the solid phases resulting in a $\mathrm{Au}$ complex that is able to induce the biosensor.

The aims of this study were to: (a) heterologously express the golTSB genes from $S$. enterica serovar typhimurium in E. coli and fuse them to a promoter-less lacZ reporter gene, under the control of the GolS regulator; (b) investigate to what extent this construct can be used as a sensitive biosensor in determining concentrations of $\mathrm{Au}(\mathrm{I})$ - and $\mathrm{Au}(\mathrm{III})$-complexes; (c) test the sensors selectivity to detect $\mathrm{Au}(\mathrm{I})$ and $\mathrm{Au}(\mathrm{III})$ when in combination with other mobile metal species relevant for mineral exploration, such as $\mathrm{Cu}(\mathrm{II})$, $\mathrm{Ag}(\mathrm{I}), \mathrm{Fe}(\mathrm{III}), \mathrm{Ni}(\mathrm{II}), \mathrm{Co}(\mathrm{II}), \mathrm{Zn}(\mathrm{II}), \mathrm{As}(\mathrm{III}), \mathrm{Pb}(\mathrm{II}), \mathrm{Sb}(\mathrm{III})$ and $\mathrm{Bi}(\mathrm{III})$; (d) assess the speciation of Au-complexes in induction solutions; (e) test the biosensor system in combination with a selective extraction technique applied to field samples.

\section{Materials and Methods}

\section{Strains and growth conditions}

All cultures were grown at $37^{\circ} \mathrm{C}$ (or $30^{\circ} \mathrm{C}$ for E. coli harbouring the plasmid pINT-ts) on Luria-Bertani (LB) broth with shaking at 120 revolutions per minute (rpm) or LB Agar (Difco BD Bioscience). Selection was established with $35 \mu \mathrm{g} \mathrm{mL}{ }^{-1}$ kanamycin $(\mathrm{Km})$ or with $100 \mu \mathrm{g} \mathrm{mL} \mathrm{m}^{-1}$ ampicillin (Amp). E. coli $X L-1$ DH5 $\alpha$ and EC100D pir-116 were used to propagate plasmids. Wild-type E. coli strain K12 (W3110) was used to construct the biosensor.

\section{Plasmid construction}

PCR fragments for cloning were constructed using primers GolTopF (5'- AAACT GCAGC GGGGA TGACG CGGGC TATCA - $3^{\prime}$ ) and GolBstopR (5'- AAAGA ATTCT ACGTC TCGCG CGGCG GGAAA C $\left.-3^{\prime}\right)$. When cut with PstI/EcoRI the resulting fragment contains the entire gol operon, ranging from 200 bp upstream of the golT start codon to the stop codon of golB. All restriction enzymes were from Promega or New England Biolabs. Plasmid pAH125-golReg was constructed following the general cloning procedure as outlined in Haldimann and Wanner (2001) [27]. The plasmid was then integrated into the E. coli W3110 genome, using the helper plasmid pINT-ts, providing the lambda phage integration functions, as described [27] (Fig. S1).

\section{Induction of the biosensor with metal ions}

All metal stock solutions were freshly prepared by dissolution in deionized water, ammonia (Fluka) or aqua regia (3 parts $\mathrm{HCl}$ : 1 part $\mathrm{HNO}_{3}$ ). The solutions were then diluted to a working concentration and the $\mathrm{pH}$ adjusted to 7.0 prior to use. A single colony was picked from LB agar plates and grown in minimal salts medium (MSM) [28] with 0.2 wt.\% glycerol or 0.2 wt.\% glucose. Cells were allowed to reach $\log$ phase (approximately $2 \mathrm{~h}$ ) then $3 \mathrm{~mL}$ of culture was added to $16 \times 100 \mathrm{~mm}$ tubes (VWR, fitted with a KIMAKAP cap). To this $0,0.05,0.1,0.5,1.0,2.0,3.0,4.0,5.0$, 6.5, 8.0 and $10.0 \mu \mathrm{M}$ of $\mathrm{Au}(\mathrm{I})$ (as $\mathrm{Au}(\mathrm{I})$-thiosulfate, Sigma-Aldrich), $0,0.05,0.1,0.5,1.0,2.0,3.0,4.0,5.0,6.5,8.0$ and $10.0 \mu \mathrm{M}$ of 
$\mathrm{Au}(\mathrm{III})$ (as $\mathrm{AuHCl}_{4} 3 \mathrm{H}_{2} \mathrm{O}$, Sigma-Aldrich) were added. For cross reactivity testing $5.0 \mu \mathrm{M}$ of $\mathrm{AgCl}, \mathrm{CuCl}_{2}$ (Sigma-Aldrich), $\mathrm{FeCl}_{3}$ (Fisher Chemicals), $\mathrm{NiCl}_{2}$ (Sigma-Aldrich), $\mathrm{CoCl}_{2}$ (Sigma-Aldrich), $\mathrm{ZnCl}_{2}$ (Sigma-Aldrich), $\mathrm{AsCl}_{3}$ (Acros Organics), $\mathrm{PbCl}_{2}$ (Acros Organics), $\mathrm{SbCl}_{3}$ (Strem Chemicals) or $\mathrm{BiCl}_{3}$ (Acros Organics) were added to cultures with $0.5 \mu \mathrm{M}$ of $\mathrm{Au}(\mathrm{I})$ or $\mathrm{Au}(\mathrm{III})$. Cultures were incubated for $16 \mathrm{~h}$ with shaking at $120 \mathrm{rpm}$ and $37^{\circ} \mathrm{C}$. Cultures were then placed on ice for $20 \mathrm{~min}$. All cultures were grown in triplicate for biosensor assays.

\section{Selective extraction}

To test the biosensor system with environmental samples, selective extractions were applied to duplicates of $\mathrm{Au}$-spiked soils. Soils from four physicochemical distinct Australian sites not containing natural Au were used (Table S1): Nullarbor (high soil$\mathrm{pH}$, high clay content, carbonate-rich), Frankland (low soil-pH, low clay content), Ora Banda (OB; low soil-pH, high clay content) and Tomakin (low soil-ph, organic-rich). Soils (10 g) were weighed and transferred to $50 \mathrm{~mL}$ centrifuge tubes, spiked with $10 \mathrm{~mL}$ of $0.1 \mu \mathrm{M} \mathrm{Au}(\mathrm{III})$-chloride $(\mathrm{aq})$ solution and shaken at room temperature for 10 days. Soils were dried overnight in a $60^{\circ} \mathrm{C}$ oven. Subsequently, soils were subjected to an overnight extraction using $10 \mathrm{~mL}$ of $1 \mathrm{M}$ sodium-thiosulfate solution on an overhead shaker, in the dark. Soils were centrifuged at $3000 \mathrm{rpm}$ at $4^{\circ} \mathrm{C}$ for $30 \mathrm{~min}$ and the supernatant was decanted. Finally, the supernatant was syringe filtered with a sterile $0.22 \mu \mathrm{M}$ filter. ICP-MS (Agilent $7500 \mathrm{ce}$, Agilent Technologies; CSIRO Land and Water, Adelaide, Australia) was used to determine the concentration of $\mathrm{Au}$ in the extraction solution. The extraction solutions were used to induce the biosensor. Based on the ICP-MS results, solutions were diluted to $0.5 \mu \mathrm{M}$ of $\mathrm{Au}$ (a dilution factor of approx. 200) using MSM. Triplicates of each of the extractions were subsequently analyzed using the biosensor.

\section{$\beta$-galactosidase assay}

Initial testing of mutants and their responses to $\mathrm{Au}(\mathrm{I} / \mathrm{III})-$ complexes was carried out using a standard $\beta$-galactosidase assay [29] with minor changes. In short, the following procedure was carried out in a $30^{\circ} \mathrm{C}$ temperature controlled room. To $10 \mu \mathrm{L}$ of culture the following components were added, in the order listed: $1 \mathrm{~mL}$ of Buffer $\mathrm{Z}\left(10 \mathrm{mM} \mathrm{KCl}, 1 \mathrm{mM} \mathrm{MgSO} 4,2.7 \mathrm{~mL} \mathrm{~L}^{-1}\right.$ mercaptoethanol, freshly prepared in sodium phosphate buffer); $100 \mu \mathrm{L}$ of chloroform; and $50 \mu \mathrm{L}$ of $0.1 \%$ SDS. The cells were then mixed by vortex and $200 \mu \mathrm{L}$ of $4 \mathrm{mg} \mathrm{mL}^{-1}$ orthonitrophenyl- $\beta$-galactoside (ONPG) was added. The specific $\beta$ galactosidase activity was expressed as Miller Units (MU) [30].

\section{Electrochemical assaying}

Electrochemical detection of the presence of trace metal complexes is also possible through the use of the same reporter enzyme, $\beta$-galactosidase. It takes the substrate $\mathrm{p}$-aminophenyl- $\beta$ $\mathrm{D}$-galactopyranoside (PAPG), which is electrochemically inactive, but when converted by $\beta$-galactosidase to $\mathrm{p}$-aminophenyl (PAP), is electrochemically active as an electron donor. The electrode, at a constant potential of $220 \mathrm{mV}$ vs. $\mathrm{Ag} / \mathrm{AgCl}$, can then permanently oxidize enzyme-generated PAP to 4-iminocyclohexa-2,5-dienone. This allows for real time detection of PAP. The substrate PAPG was not added to the electrode until $15 \mathrm{~s}$ into the run to reduce the non-faradaic signal. A single scan was taken in $180 \mathrm{~s}$ and the change in the current over time was measured.

To conduct these measurements using the electrochemical system, the clone of the biosensor that resulted in the greatest sensitivity for $\mathrm{Au}(\mathrm{I} / \mathrm{III})$-complex detection using the $\beta$-galactosidase assay was chosen for further testing. In addition to testing the sensitivity of the system to $\mathrm{Au}(\mathrm{I} / \mathrm{III})$-complexes alone, cross reactivity of $\mathrm{Cu}(\mathrm{II}), \mathrm{Ag}(\mathrm{I}), \mathrm{Fe}(\mathrm{III}), \mathrm{Ni}(\mathrm{II}), \mathrm{Co}(\mathrm{II}), \mathrm{Zn}(\mathrm{II}), \mathrm{As}(\mathrm{III})$, $\mathrm{Pb}(\mathrm{II}), \mathrm{Sb}(\mathrm{III}), \mathrm{Bi}(\mathrm{III})$ and $\mathrm{Au}(\mathrm{I})$ or $\mathrm{Au}(\mathrm{III})$ as well as $\mathrm{Au}$ extracted selectively from spiked field samples was tested using the electrochemical assays.

All electrochemical assays were conducted using the following procedure: after $20 \mathrm{~min}$ on ice, $1 \mathrm{~mL}$ of cell culture was transferred to a $1.5 \mathrm{~mL}$ centrifuge tube and centrifuged at maximum speed for $60 \mathrm{~s}$. The supernatant was removed and cells were re-suspended in $1 \mathrm{~mL}$ of phosphate buffer $(\mathrm{PB}, \mathrm{pH}$ 7.4), $50 \mu \mathrm{L} 10 \%$ SDS and $100 \mu \mathrm{L}$ chloroform (in that order) then mixed by vortex for $30 \mathrm{~s}$. This was centrifuged at maximum speed for $60 \mathrm{sec}$ and $900 \mu \mathrm{L}$ of this was added to the electrochemical chamber followed by $100 \mu \mathrm{L}$ of $4 \mathrm{mg} \mathrm{mL}^{-1}$ electrogenic substrate PAPG. The reagents potassium ferricyanide and potassium ferrocyanide were used as received (Sigma-Aldrich). All other chemicals were of analytical grade and made with deionized water purified through a Milli-Q system (DI; 18.2 M $2 \bullet \mathrm{cm}$, Millipore).

Electrochemical measurements were performed at room temperature using a CHI 1040A or 600D Electrochemical workstation with three electrodes (CH Instruments). The working electrode was a glassy carbon electrode (GCE) with a geometric area of $007.068 \mathrm{~mm}^{2}$. The counter electrode was a platinum $(\mathrm{Pt})$ wire. The pseudo-reference electrode was a $\mathrm{Ag}$ wire that was calibrated against a $\mathrm{Ag} / \mathrm{AgCl}(3 \mathrm{M} \mathrm{KCl})$ reference electrode using ferricyanide/ferrocyanide as the redox standard $(2.5 \mathrm{mM}$ ferricyanide, $2.5 \mathrm{mM}$ ferrocyanide, $8.02 \mathrm{mM} \mathrm{Na} \mathrm{HPO}_{4}, 1.98 \mathrm{mM} \mathrm{NaH}{ }_{2} \mathrm{PO}_{4}$, $1 \mathrm{M} \mathrm{NaCl}, \mathrm{pH}$ 7.4).

The GCE was polished using $1 \mu \mathrm{m}$ aqueous diamond slurry (Buehler) to a mirror finish. The electrode was then rinsed with DI water and sonicated for $30 \mathrm{~s}$ to remove bound particulates. Prior to the chronoamperometric experiments, the Ag pseudo-reference electrode was first calibrated using the ferricyanide/ferrocyanide redox couple. To oxidize the enzymatic product, $\mathrm{p}$-aminophenol, to $\mathrm{p}$-iminoquinone, an oxidizing potential of $+220 \mathrm{mV}$ (vs. Ag/ $\mathrm{AgCl}$ ) was applied to the GCE. Pure $\beta$-galactosidase and the substrate, PAPG, were added to the buffer solution approximately $15 \mathrm{~s}$ after the potential was applied. Measurements were conducted in triplicates for all enzyme concentrations used in this study and the slopes of the chronoamperograms (i.e., current-time plots) were used to generate a calibration plot for $\beta$-galactosidase enzymatic activity. The same procedure was used to measure the activity of $\beta$-galactosidase in cell lysates of $E$. coli grown with the various metals and selective extractions.

\section{Geochemical modeling}

To establish the initial composition of aqueous Au species in the MSM is important, because Au speciation influences cellular responses, and it cannot be assumed that the addition of a solid Au compound, e.g., sodium-tetrachloroaurate(III)-hydrate or sodiumgold(I)-thiosulfate hydrate to MSM will result in the formation of $\mathrm{Au}(\mathrm{III})$-chloride(aq) and or $\mathrm{Au}(\mathrm{I})$-thiosulfate(aq) complexes. Hence, a chemical model for the speciation of sodium-tetrachloroaurate(III)-hydrate and sodium-gold(I)-thiosulfate hydrate in MSM was calculated. Calculations were conducted using Geochemist's Workbench (GWB; [31]). Thermodynamic properties were taken from the Lawrence Livermore National Laboratory database (version R9), and properties for gold complexes from Usher et al. [32].

\section{Data analysis and statistics}

Microsoft Excel was used to graph the data, and the inbuilt function was used to determine the lines of best fit, their subsequent equations and $\mathrm{R}^{2}$ values. The one tailed t-test was 
used to calculate the difference between means when investigating the differences between measurements taken with and without additional metals, $\mathrm{P}<0.05$ and $\mathrm{P}<0.10$ was used as significance cut off values, as reported in results. Analysis of variance (ANOVA) was used to calculate differences between gold measured using ICP-MS and the biosensor.

\section{Results}

\section{Transgenic biosensor induction by $\mathrm{Au}(\mathrm{I})$ - and $\mathrm{Au}(\mathrm{III})-$} complexes

The E. coli biosensor tested in this study harboured the golTSB operon with a transcriptionally fused lacZ reporter gene controlled by the GolS regulator (Fig. 1). Using the $\beta$ galactosidase assay, a linear relationship was established between $\mathrm{MU}$ and $\mathrm{Au}$ concentrations with both $\mathrm{Au}(\mathrm{I})$ and $\mathrm{Au}(\mathrm{III})$ between 0.1 and $5.0 \mu \mathrm{M}$ (equivalent to 20 to $1000 \mathrm{ng} \mathrm{g}^{-1}$ or parts-per-billion (ppb); $\mathrm{R}^{2}=0.988$ and 0.971 respectively; Fig. 2). Outside of this range $(0.01,0.05$ and 6.0 to $10 \mu \mathrm{M}) \mathrm{Au}$ was detected but a greater variation in results was seen and high SD meant that the quantitative results were not statistically significant (Fig. 2).

Gold(I) and $\mathrm{Au}(\mathrm{III})$ concentrations can be determined from the $\beta$-galactosidase assay using the following equations: $[\mathrm{Au}(\mathrm{I})]=(\mathrm{MU}$ $+11.292) / 590.87\left(\mathrm{R}^{2}=0.988\right)$ and $[\mathrm{Au}(\mathrm{III})]=(\mathrm{MU}-134.25) /$ $383.44\left(\mathrm{R}^{2}\right.$ of 0.971$)$. At $\mathrm{Au}$ concentrations between 0.1 and $1.0 \mu \mathrm{M}$ the concentration of $\mathrm{Au}(\mathrm{I})$ and $\mathrm{Au}(\mathrm{III})$ can be determined with the same equation, meaning that a total concentration of $\mathrm{Au}$ could be determined $\left(\left[\mathrm{Au}_{\text {total }}\right]=[\mathrm{Au}(\mathrm{I})]+[\mathrm{Au}(\mathrm{III})]\right)$. At these concentrations $(0.1$ to $1 \mu \mathrm{M})$ there was no significant difference between the number of MU for $\mathrm{Au}(\mathrm{I})$ or $(\mathrm{III})(\mathrm{P}<0.05)$. The total amount of $\mathrm{Au}$ at these concentrations can be given by $\left[\mathrm{Au}_{\mathrm{total}}\right]=(\mathrm{MU}-64.04) / 482.07\left(\mathrm{R}^{2}\right.$ of 0.991$)$.

Results for the electrochemistry were comparable to the $\beta$ galactosidase assays. The cells responded to the concentration of Au complexes linearly, although there was a "toxicity" level, in which the cells die because of too much $\mathrm{Au}$ in the growth media. This linearity was quantified using chronoamperometry (Fig. 2). Gold concentrations of 0.01 to $10 \mu \mathrm{M}$ were tested and concentrations of 0.1 to $5 \mu \mathrm{M}$ could be measured reliably and reproducibly ( $\mathrm{R}^{2}>$ of 0.95 ; Fig. 2 ). Similar to the $\beta$-galactosidase assay, the $\mathrm{Au}(\mathrm{I})$ species also demonstrated a greater ability to induce the biosensor. The equation generated to determine the concentrations of Au calculated from the of the Amperometric IT
Slope $\left(-\mathrm{nAs}^{-1}\right) \quad$ is: $\quad[\mathrm{Au}(\mathrm{I})]=\left(-\mathrm{nAs}^{-1}-0.1563\right) / 0.1795$ $\left(\mathrm{R}^{2}=0.998\right)$ and $[\mathrm{Au}(\mathrm{III})]=\left(-\mathrm{nAs}^{-1}-0.094\right) / 0.035\left(\mathrm{R}^{2}=0.995\right)$.

\section{Geochemical modeling}

Using the REACT routine in GWB, titration curves for the addition of up to $10 \mu \mathrm{M}$ sodium-tetrachloroaurate(III)-hydrate, $10 \mu \mathrm{M}$ sodium-gold(I)-thiosulfate hydrate, to MSM under thermodynamic equilibrium conditions were calculated (Fig. 3). Results showed that in MSM amended with sodium tetrachloroaurate(III), $>99.9$ wt. $\%$ of $\mathrm{Au}$ exists as a $\mathrm{Au}(\mathrm{III})$-tetra-ammonium-complex at $\mathrm{pH} \mathrm{7,} \mathrm{i.e.,} \mathrm{the} \mathrm{pH}$ of the medium and the selective extractions. In MSM titrated with $\mathrm{Au}(\mathrm{I})$-sodium-thiosulfate $>99.9$ wt. $\%$ of $\mathrm{Au}$ exists as a $\mathrm{Au}(\mathrm{I})$-bi-ammonium complex at $\mathrm{pH}$ 7. Titration curves at $\mathrm{pH} 7$ with up to $10 \mu \mathrm{M}$ of sodiumtetrachloroaurate(III)-hydrate and sodium-Au(I)-thiosulfate hydrate, showed that at all concentrations below $10 \mu \mathrm{M}$ more than $>99.9$ wt. $\%$ of soluble $\mathrm{Au}$ consists of $\mathrm{Au}(\mathrm{III})$-tetra-ammoniumcomplex and $\mathrm{Au}(\mathrm{I})$-bi-ammonium complexes, respectively.

\section{Transgenic biosensor induction by $\mathrm{Au}(\mathrm{I})$ - and $\mathrm{Au}(\mathrm{III})$ - complexes in combination with other metal ions}

When testing the electrochemical system with $\mathrm{Au}(\mathrm{I} / \mathrm{III})$ complexes in combination with other metals, cross reactivity was observed (Fig. 4). The concentration of the other metals was ten times that of the $\mathrm{Au}$ concentration. At $0.5 \mu \mathrm{M}$, the $-\mathrm{nAs}^{-1}$ for $\mathrm{Au}(\mathrm{I})$ averaged 0.24 , whereas when calculated using the above equation the $-\mathrm{nAs}^{-1}$ would be 0.246 . This number was used as the expected $-\mathrm{nAs}^{-1}$ for $0.5 \mu \mathrm{M}$ of $\mathrm{Au}(\mathrm{I})$. Similarly for $0.5 \mu \mathrm{M}$ of $\mathrm{Au}(\mathrm{III}), 0.15$ was observed and 0.136 was calculated and used in further analysis. Figure $4 \mathrm{~b}$ shows the expected $-\mathrm{nAs}{ }^{-1}$ for $0.5 \mu \mathrm{M}$ of $\mathrm{Au}(\mathrm{I})$ and $\mathrm{Au}(\mathrm{III})$ (i.e. 0.246 and 0.136 respectively) subtracted from the measured values. Statistical analysis showed that there were significant differences between the expected $-\mathrm{nAs}^{-1}$ and measured $-\mathrm{nAs}^{-1}$ across all samples when Au was in the presence of other metals $(\mathrm{P}>0.1)$. $\mathrm{Cu}(\mathrm{II})$ caused the most cross-reactivity, followed by $\mathrm{Fe}(\mathrm{III}), \mathrm{Ni}(\mathrm{II}), \mathrm{Pb}(\mathrm{II})$, and $\mathrm{Zn}(\mathrm{II})$. Differences were seen in the measurements taken with $\mathrm{Au}(\mathrm{I})$ and $\mathrm{Au}(\mathrm{III})$. For example, the samples with $\mathrm{Au}(\mathrm{I})$ and $\mathrm{Pb}(\mathrm{II})$ measured more $\mathrm{Au}$ in the sample than was actually present, whereas when $\mathrm{Au}(\mathrm{III})$ and $\mathrm{Pb}(\mathrm{II})$ were tested the concentration of $\mathrm{Au}$ was underestimated $(\mathrm{P}>0.1)$. Using the selective extraction, the extracted $\mathrm{Au}$ is expected to be in the form $\mathrm{Au}(\mathrm{I})$, so the equation for determining the concentration of $\mathrm{Au}(\mathrm{I})$ for the electrochemical system was used. The Au which was

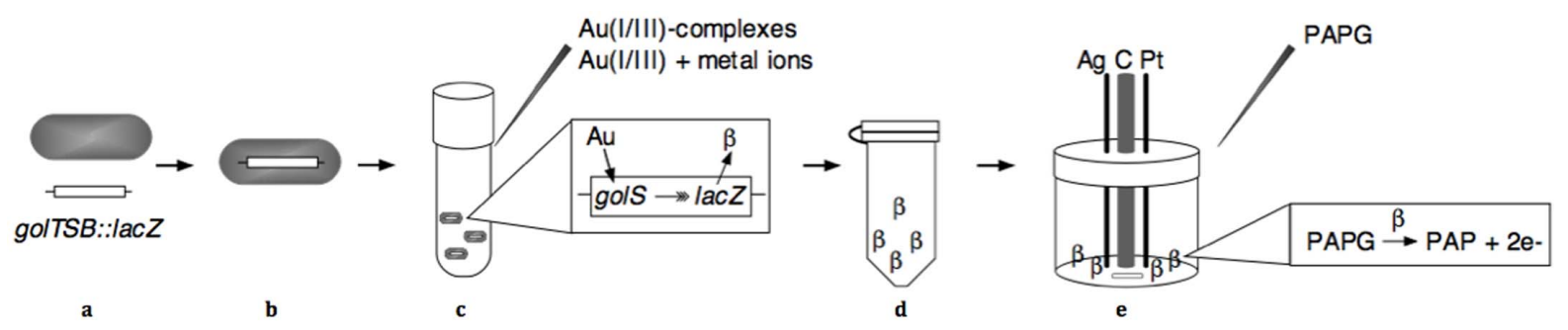

Figure 1. Schematic of methodology employed to build the Au biosensor. (a) The golTSB regulon is regulated by Au ions in Salmonella enterica serovar typhimurium. A synthetic golTSB regulon was made by fusing a promoter-less lacZ reporter gene downstream of the golB open reading frame as a transcriptional fusion. (b) This golTSB::/acZ transcriptional fusion was introduced as a single copy into the chromosome of $E$. coli. (c) A single clone was taken for further studies and incubated overnight, used to inoculate new media, then metals (various concentrations of $\mathrm{Au}(\mathrm{l})$ or $\mathrm{Au}(\mathrm{III})$ or cross reactivity testing with $\mathrm{Cu}(\mathrm{II}), \mathrm{Ag}(\mathrm{I}), \mathrm{Fe}(\mathrm{III}), \mathrm{Ni}(\mathrm{II}), \mathrm{Co}(\mathrm{II}), \mathrm{Zn}(\mathrm{II}), \mathrm{As}(\mathrm{III}), \mathrm{Pb}(\mathrm{II}), \mathrm{Sb}(\mathrm{III})$ and $\mathrm{Bi}(\mathrm{III})$ and $\mathrm{Au}(\mathrm{I})$ or $\mathrm{Au}(\mathrm{III}))$ were added and this was incubated for $16 \mathrm{~h}$. (d) Cells were permebabilized for access to the $\beta$-galactosidase produced by the lac $Z$ gene in the presence of Au. (e) The permeabilized cells were transferred to the electrochemical cell, $\mathrm{p}$-aminophenyl- $\beta$-D-galactopyranoside (PAPG) was added. The $\beta$-galactosidase cleaves PAPG to $\mathrm{p}$-aminophenol (PAP), the PAP is then oxidized by the carbon electrode vs. $\mathrm{Ag} / \mathrm{AgCl}$ giving off electrons (e-) and the slope of the current-time plots were used to determine $\beta$-galactosidase enzymatic activity.

doi:10.1371/journal.pone.0069292.g001 

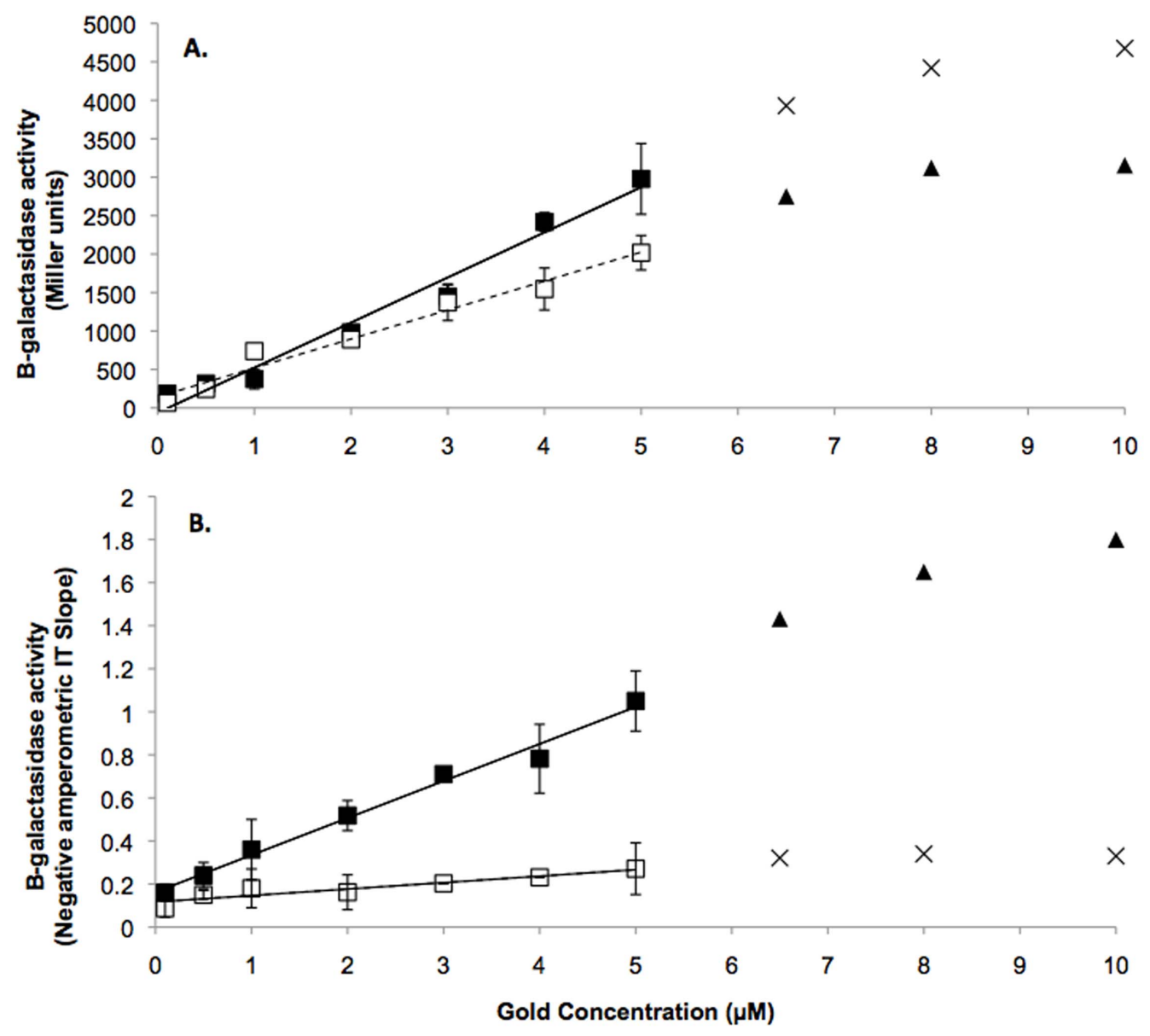

Figure 2. Linear relationship between Au concentrations measurable functional units. These graphs show the concentration of Au measured using the biosensor. (a) Measurements from the $\beta$-glactasidase assay, when 0.1 to $5.0 \mu \mathrm{M}$ of $\mathrm{Au}(\mathrm{I})$ and $\mathrm{Au}(\mathrm{III})$ were used to induce the biosensor. A linear relationship could be established, outside of this range no relationship between Au concentration and $\beta$-glactasidase activity was measured, as shown in triangles for $\mathrm{Au}(\mathrm{l})$ and crosses for $\mathrm{Au}(\mathrm{III})$. (b) Electrochemistry results when 0.1 to $5.0 \mu \mathrm{M}$ of $\mathrm{Au}(\mathrm{I})$ and $\mathrm{Au}(\mathrm{III})$ were used to induce the biosensor and a linear relationship was established, outside of this range no relationship between Au concentration and $\beta$-glactasidase activity was measured, as shown in triangles for $\mathrm{Au}(\mathrm{I})$ and crosses for $\mathrm{Au}(\mathrm{III})$. The solid box and line shows $\mathrm{Au}(\mathrm{I})$. The open box and dashed line shows $\mathrm{Au}(\mathrm{III})$. The boxes refer to the means, the capped lines show the standard deviation and the line of best fit is also shown (this shows the line formed by the equations used to determine the Au concentration measured from an unknown solution by the biosensor).

doi:10.1371/journal.pone.0069292.g002

Minimal medium (Mergeay et al., 1985)

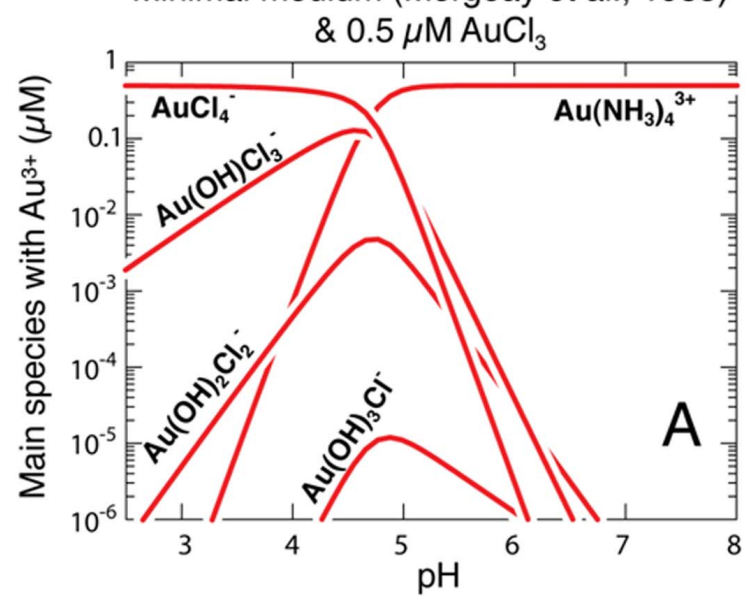

Minimal medium (Mergeay et al., 1985)

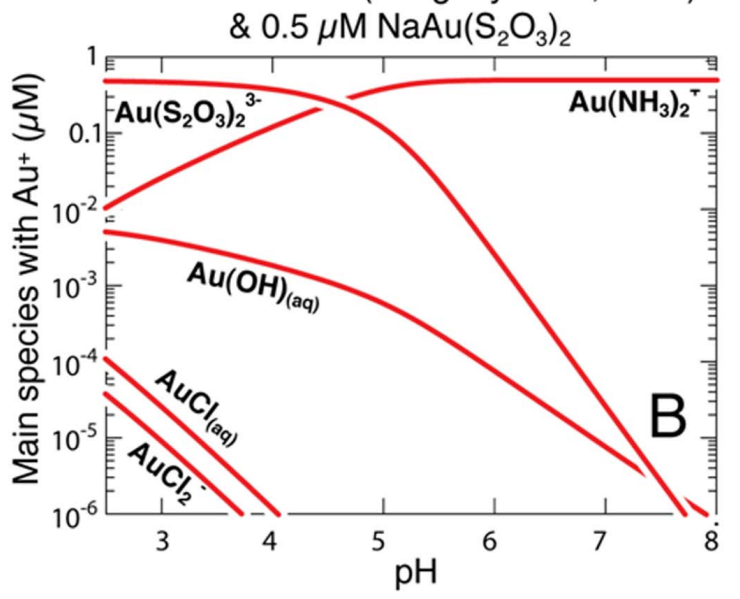

Figure 3. Chemical model showing the speciation of Au in growth media as a function of pH and oxidation state of Au. Chemical model, using Geochemist's Workbench (GWB; [31]), showing the speciation of $0.5 \mu \mathrm{M} \mathrm{NaAu}(\mathrm{III}) \mathrm{Cl}_{4(\mathrm{~s})}$ (a) and $0.5 \mu \mathrm{M} \mathrm{Na} \mathrm{Au}(\mathrm{I})\left(\mathrm{S}_{2} \mathrm{O}_{3}\right)_{2(\mathrm{~s})}(\mathrm{b})$, in minimal salt media (MSM, [28]) at pHs 2 to 8.

doi:10.1371/journal.pone.0069292.g003 


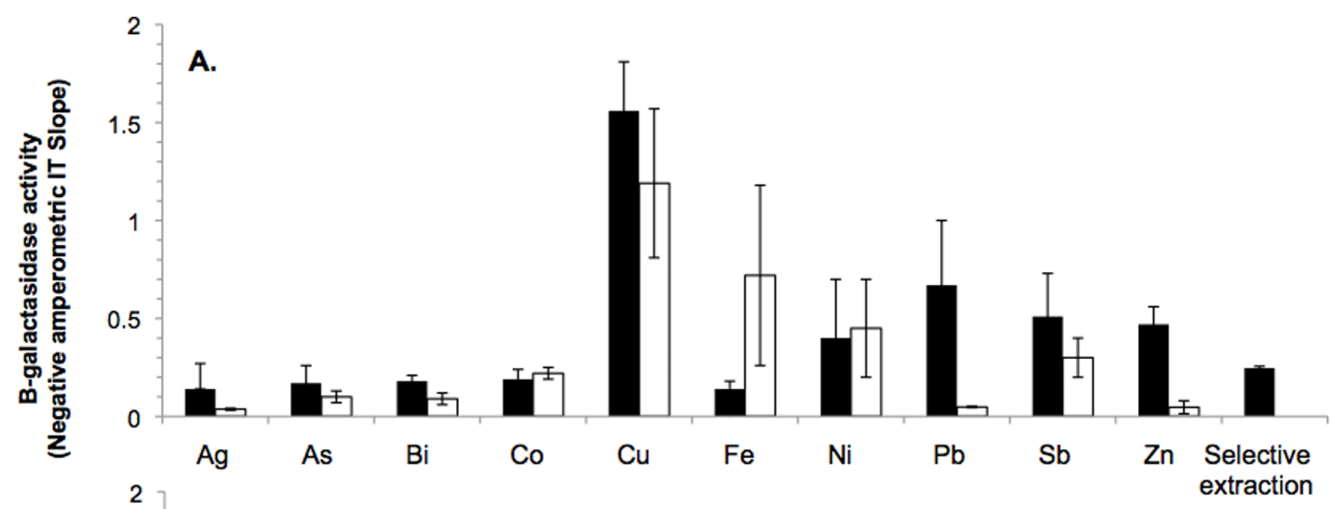

B.

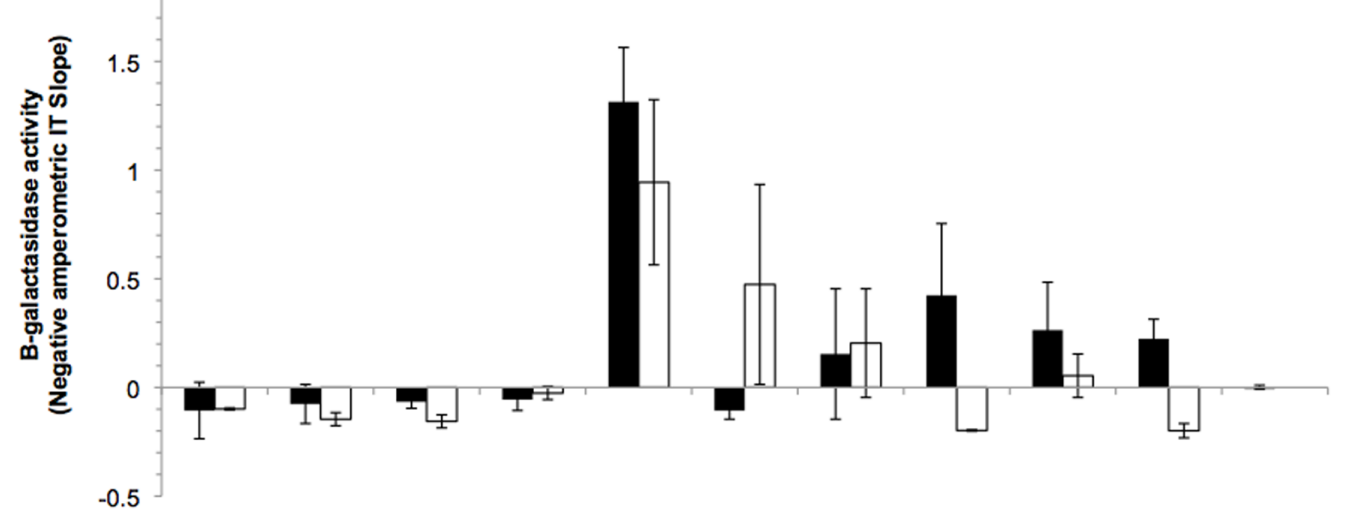

Figure 4. Interference of other metals on the detection and quantification of gold by the biosensor. At the induction stage cross reactivity was tested by adding $5.0 \mu \mathrm{M} \mathrm{Cu}(\mathrm{II}), \mathrm{Ag}(\mathrm{I}), \mathrm{Fe}(\mathrm{III}), \mathrm{Ni}(\mathrm{II}), \mathrm{Co}(\mathrm{II}), \mathrm{Zn}(\mathrm{II}), \mathrm{As}(\mathrm{III}), \mathrm{Pb}(\mathrm{II}), \mathrm{Sb}(\mathrm{III})$, or $\mathrm{Bi}(\mathrm{III})$ and $0.5 \mu \mathrm{M} \mathrm{Au}(\mathrm{I})$ or $\mathrm{Au}(\mathrm{III})$. $\mathrm{Measurements}$ were then carried out using an electrochemistry assay as shown in (a). The solid box shows $\mathrm{Au}(\mathrm{I})$ and the open box shows $\mathrm{Au}(\mathrm{III})$, the capped lines indicate the standard deviation. The calculated $\beta$-glactasidase activity would be $0.246 \mathrm{for} A u(I)$ and $0.136 \mathrm{for} A u(I I I)$, as shown by the line of best fit in Fig. 2. (b) Measurements for the different metals with the expected $\mathrm{Au}(\mathrm{I})$ and $\mathrm{Au}(\mathrm{III}) \beta$-glactasidase activity value subtracted.

doi:10.1371/journal.pone.0069292.g004

subjected to selective extraction was measured accurately using the biosensor system $(\mathrm{P}>0.1)$.

\section{Biosensor induction by $\mathrm{Au}(\mathrm{I})$-complexes after selective extractions}

Using the biosensor, concentrations of $\mathrm{Au}$ were accurately determined in selective extraction solutions from $\mathrm{Au}$-spiked field soils. The selective extractions had been diluted to contain $0.5 \mu \mathrm{M}$ of Au based on the initial ICP-MS results. Across the four soils the concentration of $\mathrm{Au}$, as measured using the biosensor, was $0.505 \mu \mathrm{M}$ (Fig. 5). Using an ANOVA test there was no statistical differences between the measurement of soil extracts using ICPMS and the biosensor ( $\mathrm{P}>0.1$; Fig. 5). There were no apparent differences in the measurement of $\mathrm{Au}$ between soil types $(\mathrm{P}>0.1$; Fig. 5).

\section{Discussion}

An in-field, in-line detection method for Au will be beneficial for use in the mining industry, as it will make it possible for exploration geologists to obtain on-site quantification of $\mathrm{Au}$, which is not possible with current technologies. To achieve this, the gol genes of $S$. enterica seemingly provide the perfect starting material for the development of a Au biosensor, and our results indicate that this genetic determinant can be used for the quantification of $\mathrm{Au}$ ions down to $0.5 \mu \mathrm{M}(20 \mathrm{ppb})$ and the detection of $\mathrm{Au}$ ions down to $0.01 \mu \mathrm{M}(0.4 \mathrm{ppb})$. Detection of $\mathrm{Au}$ using existing technologies in commercial laboratories, such as ICP-MS, allows for the quantification of Au down to $0.025 \mu \mathrm{M}$ (1 ppb). This puts the biosensor in a similar range of Au detection, making it of great interest to the mining industry. With further refinement, the whole-cell biosensor system may make it possible to quantify Au at levels equal or below that of ICP-MS.

Gold speciation was shown to effect the biosensors ability to measure the concentrations of $\mathrm{Au}(\mathrm{I})$ and $\mathrm{Au}(\mathrm{III})$. With the colorimetric $\beta$-galactosidase assay, the concentrations of $\mathrm{Au}(\mathrm{I})$ and $\mathrm{Au}(\mathrm{III})$ could be determined using the same equation between 0.1 and $1 \mu \mathrm{M}$. Using the electrochemical assay, no linear equation could be derived across the concentrations of $\mathrm{Au}(\mathrm{I})$ and $\mathrm{Au}(\mathrm{III})$. The induction of gol and thus, lac Z was more responsive to $\mathrm{Au}(\mathrm{I})$ than $\mathrm{Au}(\mathrm{III})$, as was seen by the number of MU and the Amperometric IT Slope of the colorimetric and electrochemical assay, respectively. This contradicts the long held belief that $\mathrm{Au}(\mathrm{III})$ is more toxic to cells than $\mathrm{Au}(\mathrm{I})[33,34]$, and supports the recent research that shows the toxicity of $\mathrm{Au}$ depends on the thermodynamic stability constants of the complexes, as shown for C. metallidurans ([18], Nies personal communication). Another possibility for $\mathrm{Au}(\mathrm{I})$ having greater potential for inducting the biosensor than $\mathrm{Au}(\mathrm{III})$ could be due to differences in the growth of the microorganism. The electrochemical assay does not take into account variations in growth rates and cell numbers, which would affect the amount of the $\beta$-galactosidase protein in the cultures. The assumption is made that the cells growing at $0.1 \mu \mathrm{M}$ of $\mathrm{Au}(\mathrm{I})$ or $5.0 \mu \mathrm{M}$ of $\mathrm{Au}(\mathrm{III})$ are progressing along the same growth curve. However, again, these problems are overcome with the use of a selective 


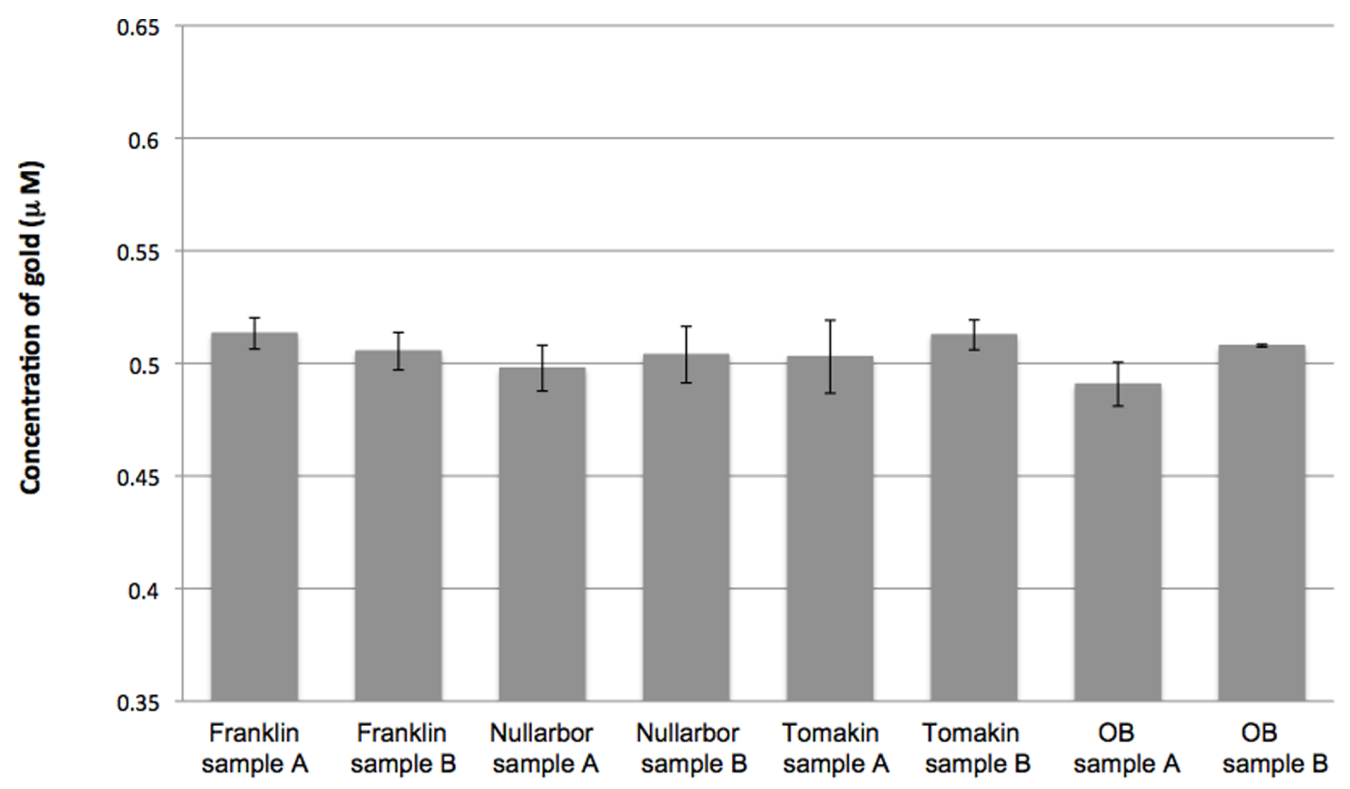

Figure 5. Spiked soil samples subjected to selective extraction and Au quantification. Soil samples from five locations were spiked with $\mathrm{Au}$ and then subjected to selective extraction using thiosulfate. The amount of resulting Au was measured with inductively coupled plasma- mass spectrometry (ICP-MS), this was compared to the measurement of Au using the biosensor. The solid boxes shows the concentration of Au as measured using the biosensor when $0.5 \mu \mathrm{M}$ of $\mathrm{Au}(\mathrm{l})$ from the selective extraction was used to induce the biosensor, the capped lines indicated the standard deviation. OB: Ora Banda. doi:10.1371/journal.pone.0069292.g005

extraction, as the speciation of $\mathrm{Au}$ is controlled by the selective extraction procedure.

A major challenge for the application of biosensors has been the less-than-rigorous testing of the systems under field conditions [16]. As a first step, the whole-cell biosensor was developed in this study and tested against a range of metals (Fig. 4). The metals chosen can be expected to be present along with $\mathrm{Au}$ in the soil, hence theoretically interfere with the use of a biosensor [35]. As the electrochemical system would form the basis of a field-based assay, it was chosen to be the system used for testing metal crossreactivity. It was found that the addition of other metals impaired the ability of the sensor to measure the concentration of $\mathrm{Au}$ accurately. This contradicted a previous study by Checa et al. (2007) where the induction of $g_{0} l B$ with $\mathrm{Cu}(\mathrm{II}), \mathrm{Ag}(\mathrm{I}), \mathrm{Zn}(\mathrm{II}), \mathrm{Cd}(\mathrm{II})$, $\mathrm{Hg}(\mathrm{II}), \mathrm{Fe}(\mathrm{II}), \mathrm{Co}(\mathrm{II}), \mathrm{Ni}(\mathrm{II})$, and $\mathrm{Pb}(\mathrm{II})$ was investigated. They reported that gol was significantly more responsive to $\mathrm{Au}(\mathrm{III})$ than to any other metals tested. However, the Checa et al. (2007) [25] study varied in a number of aspects from the one presented here. The concentrations of metals tested ranged from $10 \mu \mathrm{M}$ of $\mathrm{Hg}$ (II) to $1 \mathrm{mM}$ of $\mathrm{Cu}(\mathrm{II})(50 \mu \mathrm{M}$ of $\mathrm{Au}$ was used). These concentrations were not normalized in subsequent analyses. Most importantly, $\mathrm{Au}(\mathrm{I} / \mathrm{III})$ was mixed with the other metal ions to test if $\mathrm{Au}$ can still be detected by the sensor in the present study, whereas the Checa et al. (2007) study only investigated one metal at a time.

There may be a number of reasons why the biosensor was unable to accurately detect $\mathrm{Au}$ when in the presence of other metals (ratio of Au to metal of 1:10). Most of these are likely to be due to the inherent limitations of using a whole-cell as a biosensor. A whole-cell biosensor relies upon the induction of genes and the measurement of their gene products: hence, the cells must be incubated with the material that is to be detected. In the case of several metals in the induction solution, their toxicity to cells may inhibit cell growth. Hence, the number of gene products would be lower, resulting in an under-estimation of the concentration of $\mathrm{Au}$ in the starting material. This was observed with $\mathrm{Ag}, \mathrm{As}, \mathrm{Bi}$ and $\mathrm{Co}$
(Fig. 4). A minimal media was used to grow the cells prior to induction, possibly this media is not optimal for the growth of this microorganism. When elements such as $\mathrm{Cu}, \mathrm{Fe}$, and $\mathrm{Ni}$ were added to the media, there was possibly an increase in growth rates, hence more $\beta$-galactosidase being produced and the concentration of $\mathrm{Au}$ would be determined to be higher.

The biosensor can only measure $\mathrm{Au}$ as complexes in true solution, so solubilization must be ensured prior to measurement by the biosensor. This was demonstrated by subjecting field samples to a selective extraction technique prior to analysis with the biosensor. Generally, the objective of selective extractions is to determine the amount of an element by using a sequence of reagents with successively stronger binding fractions to extract elements (e.g., [36,37]). Selective extraction techniques for Au have been used for a long time in geochemical research: to study the association of $\mathrm{Au}$ with various soil and other regolith components; to understand how $\mathrm{Au}$ is mobilized and trapped in the regolith; to develop effective exploration strategies for $\mathrm{Au}$ deposits; and to understand the bioavailability of heavy metals (e.g., [11,13,38,39]).

When $\mathrm{Au}$ spiked soils were subjected to selective extraction $\mathrm{Au}$ could be effectively recovered. Using the biosensor to measure the concentration of recovered $\mathrm{Au}$ from the selective extraction resulted in the accurate quantification of $\mathrm{Au}$, across the range of soils from four different sites (Fig. 5). These results are very promising for the development of a commercially viable biosensor. Improvements in the times taken to extract the Au will be of great benefit to the implementation of a Au biosensor in the mining industry.

Another way of overcoming the intrinsic problems of a cellular biosensor would be to develop a system that does not require the material to be incorporated into the growth media, i.e., no induction phase. This could be achieved via a protein-based system, where proteins, independent of cells, directly interact with $\mathrm{Au}$ [40]. Using a protein based sensor may also make it possible to measure far lower concentrations of Au. This has been demonstrated by Bontidean at al. [40] who developed a biosensor that 
could measure femtomolar $\left(10^{-15}\right)$ concentrations of $\mathrm{Cu}(\mathrm{II})$, $\mathrm{Cd}(\mathrm{II}), \mathrm{Hg}(\mathrm{II})$, and $\mathrm{Zn}(\mathrm{II})$. However, protein-based biosensors have their own limitations such as low yield of recombinant protein or protein instability with real-life samples. In conclusion, we have presented the 'proof of concept' for the development of a cellular $\mathrm{Au}$ biosensor. Concentrations of Au ranging from 0.1 to $5 \mu \mathrm{M}$ (equivalent to 20 to $1000 \mathrm{ng} \mathrm{g}^{-1}$ or $\mathrm{ppb}$ ) were quantified accurately using the biosensor, whilst $\mathrm{Au}$ concentrations down to $0.01 \mu \mathrm{M}(0.4 \mathrm{ppb})$ could be detected.

\section{Supporting Information}

Figure S1 Map of plasmid created for the biosensor in $\boldsymbol{E}$. coli. The golTSB regulon from Salmonella enterica serovar

\section{References}

1. Shafiee S, Topal E (2010) An overview of global gold market and gold price forecasting. Resources Policy 35: 178-189.

2. Dugdale AL, Wilson CJL, Dugdale LJ, Funk CW, Bosnjak M, et al. (2010) Gold mineralization under cover in southeast Australia: A review of an exploration initiative for Stawell-type deposits. Ore Geology Reviews 37: 41-63.

3. Zammit CM, Cook N, Brugger Jl, Ciobanu CL, Reith F (2012) The future of biotechnology for gold exploration and processing. Minerals Engineering 32: 45-53.

4. Cohen DR, Kelley DL, Anand R, Coker WB (2010) Major advances in exploration geochemistry, 1998-2007. Geochemistry: Exploration, Environment, Analysis 10: 3-16.

5. Gray DJ, Wildman JE, Longman GD (1999) Selective and partial extraction analyses of transported overburden for gold exploration in the Yilgarn Craton, Western Australia. Journal of Geochemical Exploration 67: 51-66.

6. Reith F, Lengke MF, Falconer D, Craw D, Southam G (2007) The geomicrobiology of gold. The ISME Journal 1: 567-584.

7. Butt GRM, Lintern MJ, Anand RR (2000) Evolution of regoliths and landscapes in deeply weathered terrain - implications for geochemical exploration. Ore Geology Reviews 16: 167-183.

8. Schmidt Mumm A, Reith F (2007) Biomediation of calcrete at the gold anomaly of the Barns prospect, Gawler Craton, South Australia. Journal of Geochemical Exploration 92: 13-33.

9. Hall GEM, MacLaurin AI, Vaive JE (1995) Readsorption of gold during the selective extraction of the "soluble organic" phase of humus, soil and sediment samples. Journal of Geochemical Exploration 54: 27-38.

10. Boyle RW, Jonasson IR (1973) The geochemistry of arsenic and its use as an indicator element in geochemical prospecting. Journal of Geochemical Exploration 2: 251-296.

11. Boyle RW (1979) The geochemistry of gold and its deposits. Ottawa: Geological Survey of Canada.

12. Grimm B, Friedrich G (1988) Gold in lateritic soils from Central Bahia, Brazil. Geowissenschaftliches Lateinamerika-Kolloquium Tagungsheft Mineral 11.

13. Gray DJ, Lintern MJ (1998) Further aspects of the chemistry of gold in some Western Australian soils. Wembley, Western Australia: Cooperative Research Centre for Landscape Evolution and Mineral Exploration.

14. Lintern MJ (1989) Study of the distribution of gold in soils at Mt Hope, Western Australia. CSIRO Division of Exploration Geoscience.

15. Coker WB (2010) Future research directions in exploration geochemistry. Geochemistry: Exploration, Environment, Analysis 10: 75-80.

16. Luong JHT, Male KB, Glennon JD (2008) Biosensor technology: Technology push versus market pull. Biotechnology Advances 26: 492-500.

17. Reith F, Rogers SL (2008) Assessment of bacterial communities in auriferous and non-auriferous soils using genetic and factional fingerprinting. Geomicrobiology Journal 25: 203-215.

18. Reith F, Etchmann B, Grosse C, Moors H, Benotmane MA, et al. (2009) Mechanisms of gold biomineralization in the bacterium Cupriavidus metallidurans. PNAS 106: 17757-17762.

19. Wiesemann N, Mohr J, Grosse C, Herzberg M, Hause G, et al. (2013) Influence of copper resistance determinants on gold transformation by Cupriavidus metallidurans strain CH34. Journal of Bacteriology.

20. Vlassopoulos D, Wood SA (1990) Gold speciation in natural waters: I. Solubility and hydrolysis reactions of gold in aqueous solution. Geochimica et Cosmochimica Acta 54: 3-12. typhimurium was integrated into pGEM, then inserted into pAH125 with PstI and EcoRI. This plasmid was then introduced to $E$. coli, this was then used as a gold biosensor.

(TIF)

Table S1 Geochemistry of soils used for selective extraction.

(DOCX)

\section{Author Contributions}

Conceived and designed the experiments: RYL GG FR. Performed the experiments: GMZ DQ SG AJZ CT JB. Analyzed the data: CMZ DQ AJZ. Contributed reagents/materials/analysis tools: CMZ RYL GG CT. Wrote the paper: GMZ.

21. Reith F, Rogers SL, McPhail DC, Webb D (2006) Biomineralization of gold: Biofilms on bacterioform gold. Science 313: 233-236.

22. Reith F, Fairbrother L, Noize G, Wilhelm O, Clode PL, et al. (2010) Nanoparticle factories: Biofilms hold the key to gold dispersion and nugget formation. Geology 38: 843-846.

23. Lintern F, Etschmann B, Joel B, Shapter JG, Southam G, et al. (2013) Biomineralization of gold in biofilms of Cupriavidus metallidurans. Environmental Science \& Technology 47(6): 2628-2635.

24. Nies DH (2003) Efflux-mediated heavy metal resistance in prokaryotes. FEMS Microbiology Reviews 27: 313-339.

25. Checa SK, Espariz M, Perez Audero ME, Botta PE, Spinell SV, et al. (2007) Bacterial sensing of and resistance to gold salts. Molecular Microbiology 63: 1307-1318.

26. Checa S, Soncini F (2011) Bacterial gold sensing and resistance. BioMetals 24: $419-427$.

27. Haldimann A, Wanner BL (2001) Conditional-replication, integration, excision, and retrieval plasmid-host systems for gene structure-function studies of bacteria. Journal of Bacteriology 183: 6384-6393.

28. Mergeay M, Nies D, Schlegel HG, Gerits J, Charles P, et al. (1985) Alcaligenes eutrophus $\mathrm{CH} 34$ is a facultative chemolithotroph with plasmid-bound resistance to heavy metals. Journal of Bacteriology 162: 328-334.

29. Grass G, Otto M, Fricke B, Haney CJ, Rensing C, et al. (2005) FieF (YiiP) from Escherichia coli mediates decreased cellular accumulation of iron ad relieves iron stress. Archives of Microbiology 183: 9-18.

30. Miller JH (1972) Experiments in molecular genetics. NY: Cold Spring Harbor.

31. Bethke CM (2008) Geochemical and biogeochemical reaction modeling, second edition. New York: Cambridge University Press.

32. Usher A, McPhail DC, Brugger J (2009) A spectrophotometric study of aqueous $\mathrm{Au}(\mathrm{III})$ halide-hydroxide complexes at $25-80^{\circ} \mathrm{C}$. Geochimica et Cosmochimica Acta 73: 3359-3380.

33. Finney LA, O'Halloran TV (2003) Transition metal speciation in the cell: Insights from the chemistry of metal ion receptors. Science 300: 931-936.

34. Stoyanov JV, Brown NL (2003) The Escherichia coli copper-responsive copA promoter is activated by gold. Journal of Biological Chemistry 278: 1407-1410.

35. Reith F, Brugger J, Zammit CM, Gregg AL, Goldfarb KC, et al. (2012) Influence of geogenic factors on microbial communities in metallogenic Australian soils. ISME J: 1-12.

36. Hall GEM (1998) Analytical perspective on trace element species of interest in exploration. Journal of Geochemical Exploration 61: 1-19.

37. Hall GEM, MacLaurin AI, Garrett RG (1998) Assessment of the $1 \mathrm{M} \mathrm{NH}_{4} \mathrm{NO}_{3}$ extraction protocol to identify mobile forms of $\mathrm{Cd}$ in soils. Journal of Geochemical Exploration 64: 153-159.

38. Xueqiu W (1998) Leaching of mobile forms of metals in overburden: development and application. Journal of Geochemical Exploration 61: 39-55.

39. Reith F, McPhail DC, Christy AG (2005) Bacillus cereus, gold and associated elements in soil and other regolith samples from Tomakin Park Gold Mine in southeastern New South Wales, Australia. Journal of Geochemical Exploration 85: 81-98.

40. Bontidean I, Berggren C, Johansson G, Csöregi E, Mattiasson B, et al. (1998) Detection of heavy metal ions at femtomolar levels using protein-based biosensors. Analytical Chemistry 70: 4162-4169. 